\title{
The Police from Plush and Bread to the Investigation of Criminal Offenses - A Danish Historical Perspective
}

\author{
HENRIK STEVNSBORG*
}

\section{Introduction}

In his seminal book, The Policing Web, the late Canadian criminologist, Jean-Paul Brodeur, noted that all people are more or less inclined to automatically identify policing with crime fighting. As Brodeur points out, this is paradoxical because we do not actually know much about detective work apart from what we are able to glean from the media and literary accounts. In contrast to uniformed police work, which has been well documented in a large number of empirical studies on patrolling and turnouts, agencies such as criminal investigation units have almost entirely escaped scholarly attention. ${ }^{1}$

This lack of attention seems odd given the scope of and substantial sums spent on such activities. For example, section 2 of the Danish Police Act (2004) clearly states that it is the task of the Danish police "to prevent criminal acts" and "to halt criminal activities and to investigate and pursue criminal acts". The balance sheet of the Danish National Police also clearly specifies a total expenditure of DKK 3,354.1 million on criminal investigations in 2011, the single largest expense item of a total of DKK 8,805.8 million. ${ }^{2}$

As set out in section 1 of the Danish Police Act (2004), the police are also charged with "maintaining safety, security, peace and order". But, obviously, preventing, investigating and solving crime is a core police task.

Professor in Policing and Police Law, The Faculty of Law, University of Copenhagen. Brodeur, The Policing Web, (Oxford University Press 2010), pp. 99-100.

Politiets og anklagemyndighedens årsrapport 2011 (Balance Sheet of the Police and the Public Prosecution Service), p. 13. 
When the Danish police were established as an independent public authority in 1682 by the King's appointment of the first Police Commissioner in Copenhagen, the situation was entirely different. Fighting crime was not a police matter.

\section{Luxury and Guilds}

In 1682 the police were entrusted with only two tasks that fall under the following bizarre headings: "Prohibited Plush" and "The Bread of Impunity".

On January 17, 1684, a confectioner in Copenhagen was fined for attempting to sell "prohibited plush", and the peddler from whom he had acquired the velvety cloth likewise had to pay a penalty for selling illegal goods. At the time, the absolutist Danish State had strict rules not only about who was allowed to sell certain fabrics but also who was allowed to wear them. The so-called "luxury ordinances" were meant to dampen the King's subjects' penchant for luxury because the King believed that excessive private consumption posed a threat to the national economy. Therefore, fighting extravagance was defined as the number one task for the new Police Commissioner.

A couple of months after his accession, a revised, comprehensive "luxury ordinance" was issued, providing the Commissioner with an updated legal basis for his activities. This 1683 luxury ordinance "on dresses, weddings, childbirths and banquets", for instance, detailed how many guests citizens were allowed to invite to parties and how many courses they were allowed to serve their guests; the ordinance even regulated the number of rings permitted on the traditional Danish marzipan horn-of-plenty cakes!

The authoritarian Danish society at the time was a surveillance society. One is tempted to use the charged expression "police state", which liberal theorists of the nineteenth century introduced as a bugaboo and in sharp contrast to the constitutional state (Rechtsstaat); especially since, after 1682, the remit of the Police Commissioner's tasks was broadened to clamp down on the sale and use of not only prohibited plush but also all illegal fabrics, beverages and foodstuffs.

"The bread of impunity" is an expression found in the Bakers' Guild Ordinance of June 23, 1683. Section 5 reads: "Every baker shall be obliged to bake good bread and bread of impunity..." Accordingly, white bread should be made from wheat flour, dark bread from rye and, oddly, the King felt the need to specify that a one-kilo loaf should not weigh 985 grams. Any violation of the ordinance was punishable by fine. Section 7 of the ordinance stated that the police were responsible for checking bakers' products, and charged the Police Commissioner with conducting on-site inspections of bakeries at least every fortnight.

This strict food control was just one manifestation of the monarch's desire for improved supervision of all the guilds. The King had been dissatisfied with the guilds for 
years. They tended to be elitist bourgeois cliques with (too) close ties to the municipal authorities, and the bourgeoisie's monopolisation of the trades had led to a lack of competition, followed by decreased quality and increased prices. Consequently, in an attempt to gain more control of the guilds, the King made it the second task of the new Police Commissioner to combat abuses by the various guilds.

\section{The King's Instructions}

On June 23, 1683, the Police Commissioner received further instructions from the King. ${ }^{4}$ These instructions expanded the Commissioner's jurisdiction from the District of Copenhagen to the entire Kingdom of Denmark; he was now empowered to collect fines "without any preceding sentence, procedure and trial" and, if necessary, to confiscate property. In addition, he was made responsible for maintaining the squares and other public spaces in Copenhagen. To enable him to carry out this task, the "city officials" were placed under the Commissioner's command.

The King's instructions were extremely brief and haphazard, and the King could hardly have meant for them to be an adequate delimitation of the Commissioner's responsibilities. Indeed, the Commissioner did not confine himself to the tasks outlined in the King's instructions. On December 29, 1683, he managed to push lamplighters and night watchmen under his jurisdiction, utilising these men as a night-time police force. By 1684 his authority had extended to arresting male vagrants, and - failing to induce them to obtain regular work - he was permitted to hand them over to "any officer" for enrolment in the armed forces. Female vagrants were "to be delivered to the spinning house", where they were to be confined and forced to work as spinners.

Making arrests is a fundamental resource available to the police as is the right to search citizens and their homes. Accordingly, on April 29, 1684, the Police Commissioner was given explicit "permission to carry out domiciliary visits". By the way, it seems as if the police control of the poor - instead of the wealthy who could afford to wear plush or were members of the guilds - was now brought into focus.

\section{$4 \quad$ Panoptic Program}

Within a few years, the responsibilities of the police expanded dramatically. Both the 1691 instructions for the Police Commissioner and the Major Police Regulation from 1701 list an overwhelming and varied number of police duties. Apart from the two main tasks from 1682 (fighting luxury and controlling the guilds), the police were now also required to prevent any violation against the Evangelical-Lutheran religion and to control brothels, vagrancy, gambling, public disorder, the use of fireworks and the throwing of water, rubbish and snow. Moreover, the police were tasked with monitoring closing

$4 \quad$ Koch, "Politimyndighedens oprindelse", Historisk Tidsskrift (1982), pp. 34-45. 
hours, ensuring that servants behaved and patrolling streets and squares as well as lakes and sluices. Furthermore, they were now also tasked with assisting with fire fighting and water supply services.

I should stress here that the police were expected to operate proactively and not only retroactively in response to complaints from the citizens (or government agencies).

Their duties, according to this rather panoptic program, fell entirely outside the criminal justice system. In accordance with the preface to the 1683 Danish Code, police matters were deliberately excluded from the code since a sharp distinction was drawn between 'Police', which functioned outside the criminal law, and 'Justice', which maintained the administration of justice within the criminal law. In those days, it was up to the accuser to conduct the criminal investigation and gather evidence against the defendant. Furthermore, the accuser had to take the case to court at his/her own expense. The Police Commissioner was consequently reprimanded by the King in 1687 when he had investigated cases "of debts, rents, brawls, thefts, fornications and the like". ${ }^{5} \mathrm{He}$ was not supposed to interfere with 'Justice'. Fighting crime was specifically not a police matter.

\section{$5 \quad$ A Murderer and a Suspicious Lady}

Nevertheless, there are examples from the eighteenth century of the police investigating criminal offenses. When, for instance, on November 17, 1717, a mercenary was shot dead in one of Copenhagen's side streets, the police became involved. ${ }^{6}$ Numerous witnesses were interviewed, and the perpetrator - on horseback and dressed "in a bright coat, wearing a white wig and carrying a black bag on his back, an English whip and two pistols" - was, perhaps somewhat surprisingly, soon identified as a divinity student by the name of Peter Christian Lyngby. His lodgings were searched by the police, who quickly located his horse, his clothes and his pistols. His mail was intercepted, and the police even conducted a forensic examination of the wad from the dead soldier's chest, to no avail. In the words of the Commissioner at that time, Johan Bartram Ernst, "[ $t]$ he examination of the wad which was found on the deceased's chest did not yield any results. The regimental barber, who conducted the examination, testified that the wad was made from paper, but, since it was soaked by blood, was unable to determine whether it was grey or white. It has now disintegrated because of the policemen's continued handling of it". However, by that time Lyngby had fled Copenhagen, and - in spite of a large-scale manhunt conducted by officers from the Copenhagen City Police - managed to remain at large for a couple of years. He was eventually apprehended in Jutland and convicted of murder.

The only reason the police became involved in this matter was that the King had expressly ordered the Commissioner to investigate the case. Similarly, the King was the

Stevnsborg (2010), p. 18.

Christensen, "Daglige Begivenheder i København 1716-22: Indberetninger fra Politimester Ernst til Kongen", Historiske Meddelelser om København, 1st Series, Vol. VII, (1920), pp. 343-349. 
initiator when, in the 1760s, a suspicious lady with the fabulous name of Anna Sophia Magdalena Friderica Ulrica von Koppelou showed up in Copenhagen pretending to be a daughter of the late King Christian VI and the Grand Duchess of Friesland. ${ }^{7}$ In order to verify whether she was indeed a true princess, the King set up a special committee consisting of three prominent members, among them the King's legal consultant. On behalf of the King, the committee ordered the police to have the woman arrested. However, the arrest was not without problems: the lady was lodging with a ticketing officer at the time who did not immediately acknowledge the Police Commissioner's jurisdiction.

Instead of sentencing Ms. Koppelou to a well-deserved public flogging (which might have aroused a scandal), the special committee recommended that the King have her quietly spirited away to a distant prison. The Police Commissioner was subsequently made responsible for transporting her to Møn Gaol, where she remained imprisoned for 33 years. As shown by the Danish police historian, Rune Rye Windfeld, in this case the police were only called upon to do the rough work. The actual criminal investigation was conducted by a special committee.

However, in a set of new Directions of March 24, 1741, explicitly focusing on enhancing his position, the Police Commissioner was granted investigative powers of his own in cases of theft.

Section 3-5 of the Directions read as follows:

If anybody files a complaint that they have been betrayed and robbed by evil people and requests the assistance of the police in order to have the guilty perpetrators, fences and accomplices arrested, or requests that they be summoned and subjected to interrogation and examination, the Commissioner (although the complainant is himself responsible under the law, if he imputes and charges anybody without a warrant) shall be obligated to summon said people for interrogation and examination whose names are mentioned in the complaint, as well as any such people who, by their utterances, are found to be implicated in the case ... When, in such cases, the examination has been held and testimonies given, the Commissioner shall pass on the complaint, along with a transcript of the examination and the testimonies, to the municipal authorities. In major cases of theft or similar cases of fraud, or if the accused has previously been found guilty of theft, the authorities shall, without delay, arrange for a statutory lawsuit to be filed against the guilty party with the City Court in order to have him sentenced and punished properly ... If, however, it is a minor case of theft, and if the defendant has not previously been sentenced for theft, and if the complainant states that he prefers that the defendant, instead of receiving the severe punishment according to the strict criminal law, be sentenced by the Commissioner [...] as a means of correction, the Commissioner, if the defendant declares that he is satisfied with the Commissioner's ruling, may, with due consideration of the circumstances, sentence the guilty party to minor corporal punishment, such as imprisonment on bread

Windfeld, Politiinstitutionens rolle i eneveeldens magtudøvelse, Unpublished dissertation (history), (University of Copenhagen 2009, pp.) 91-93. Stampe, Erkloeringer, Breve og Forestillinger, General-Prokureur-Embedet vedkommende, VI (Gyldendalske Boghandlings Forlag 1807), pp. 214-239. 
and water, the Spanish Cloak, the pillory, the spinning house or another arbitrary punishment...

As evidenced by this excerpt, the police did not proactively engage in criminal investigations. The police had to wait for the victim to file an official complaint. However, in 1751, the arrangement of 1741, which blurred the boundaries between "Police" and "Justice", was once again abandoned. The practice of having crime victims be made responsible for prosecuting perpetrators remained in place.

\section{$6 \quad$ High Policing}

The reactionary response to the French Revolution led to a general strengthening of police forces all across Europe, first and foremost with the aim of combating liberal or revolutionary movements. The Danish police, as part of this strengthening, began to operate proactively within the criminal justice system. This was, for instance, discussed in a textbook by professor Kolderup-Rosenvinge, published in 1825 and meant for his lectures on police law (which in 1821 became a mandatory subject of study at the Faculty of Law at the University of Copenhagen). Kolderup-Rosenvinge here mentioned police duties related to health, welfare and housing, which all fell outside criminal justice. But he also included police duties related to security, which he divided into private (i.e. with citizens offending against each other) and public (i.e. with citizens offending against the state). Kolderup-Rosenvinge added that "to achieve their aim, police in charge of security must establish a comprehensive and close system of surveillance".

This meant that during the late stages of Danish absolutism, a French-inspired "high policing" model was introduced with widespread use of informants and secret agents. The "police spying" expenses were recognised under an accounting item entitled "secret expenses" of which the police did not have to provide any disclosure. The spies were used in political cases, in particular against the liberal clubs and associations of the period. They were, for instance, used in 1821 in the infamous case against Dr. Dampe. No one knows for sure whether Dampe was just a harmless political dreamer or whether he and his ideas of a democratic constitution indeed posed a serious threat to Danish absolutism. However, there is no doubt that Dampe's small organisation was completely infiltrated by the police. He was sentenced to death for high treason, but the sentence was later commuted to life in prison. In 1848, when absolutism came to an end, he was amnestied. ${ }^{9}$

Notably, the police did not depend on spies exclusively for political ends. Informants and secret agents were involved in even the most trivial criminal cases; and clandestine operations were routinely organised in order to penetrate the criminal underworld. A couple of trials before the Supreme Court between 1823 and 1824 demonstrated the

Kolderup-Rosenvinge, Grundrids af den danske Politiret, 2nd ed., (Gyldendal 1828), p. 28.

Birkmann, "Et indbrud begået i Guldalderen" in Politihistorisk Selskabs Årsskrift (2000), pp. 5-36. 
Court's reluctance in accepting the use of spies in petty cases of theft. In one of these cases, the informant, Iver Abraham, was purposely withheld at the trial. The Copenhagen Police dared not ignore his information, but also they did not wish "to extend their hand to the inducements and inveiglements" of Mr. Abraham, and they therefore proceeded in an unorthodox manner by simply sending the informant abroad. In 1823, assisted by the police, Iver Abraham therefore boarded a vessel destined for Rio de Janeiro.

The practices of "high policing" were further elucidated by the Copenhagen Police in 1838 when the British Foreign Office officially asked Denmark to answer no less than 81 questions concerning "the organisation and administration of any constabulary, rural, or other force, which may exist for the prevention of crime within the town and rural districts of Denmark". ${ }^{10}$ Questions $45-48$ dealt with "high policing". They read as follows in the original English text:

45. To what extent and in what cases is the agency of spies used as a means of obtaining information, either for the prevention of Crimes or for the detection of Offenders? 46. What description of Persons are used as spies? 47. Are any and what means used to gain information from Offenders themselves? 48. Is much information commonly gained by such means?

In 1839 the Danish Chief of Police Andreas Kierulff delivered his official response. He wrote:
We receive and take advantage of information about impending or committed criminal acts, and we also reward it, when appropriate. When such information is not offered out of sheer respect for the law and without any egoistic motive, it generally - possible exceptions include cases where a considerable reward is legally determined; for instance, regarding detection of the production of counterfeit banknotes - comes from the criminal classes or from people connected with them, and the informant is usually motivated by either disagreement, hatred or vengefulness, or by selfishness, hoping for a reward. This consists of money or other kinds of assistance. Through the information provided by the latter group, the police acquire knowledge of the prominent criminals' connections and schemes, in particular, their planned acts of crime... The utility of this practice is twofold in the sense that it partly provides the police with the necessary information to directly prevent or detect criminal acts, and it partly causes anxiety among the criminals, which indirectly prevents the realization of many of their plans. It goes without saying that the information thus procured is used with the utmost care, ensuring that innocent people are not harmed by unreliable reports, and that it does not cause inducements.

These investigative methods brought the police into disrepute among liberal-minded citizens, and so did the ruthless manner in which the police upheld public order. ${ }^{11}$ However, 
at the end of the 1830s, the police were still quite unaffected by the political reality that absolutism in Denmark was coming to an end. Consequently, the Copenhagen Police faced strong opposition in the last years of the King's absolute rule. In a large-scale campaign, the liberal daily newspaper, Fodrelandet, made mention of brutish "rod-swinging" police officers, of "police despotism" in general and of a corrupt police force that, because of low wages, had to go cap in hand begging the citizens for funds on New Year's Eve. This degrading custom was known as "New Year's Congratulations".

\section{$7 \quad$ Police Reform}

As mentioned, absolutism came to an end in 1848, and in 1849 Denmark got a democratic constitution in which the citizens were guaranteed constitutional rights. But what about the police? The absolutist "trashing system" lived on as if nothing had happened until it was finally abolished following violent street fights between police and citizens around New Year 1859/1860. The riots continued until January 10, 1860 when the hussars raided the streets of Copenhagen. The incident is known as the "New Year's Revolt", and it is infamous for its excessive use of police violence. The police used their rods indiscriminately on both violent instigators and innocent demonstrators, which further provoked the public as well as the media. Stressing the fact that 12 years had elapsed since the end of absolutism, Fedrelandet, which had been critical of the police for years, wrote:

\footnotetext{
If this obsolete, totally condemnable and, for the police themselves, demoralising system lives on for another 12 years, it will lead not only to rioting, as in the recent evenings, but to an insurrection - as sure as there is still some resistance and a sense of honour left among the population of Copenhagen. Therefore, the system must be changed. Now is the time!
}

In 1863, the Copenhagen Police were eventually reformed. ${ }^{12}$ The old police force was dismissed, and the officers had to reapply for their former positions. Additionally, the Police Commissioner was told that the Government wanted a new Commissioner to implement the reform. The night watchmen, as a night-time police force, were fused with the regular (daytime) police to form a single unit. The new police force would patrol demarcated beats, and the rod, an offensive weapon, was replaced by the baton, a defensive weapon. Moreover, the police officers would now wear a legible number on their uniform, making it possible for citizens to file complaints against them, if necessary. In addition, a new, comprehensive Police Regulation for Copenhagen would be drafted.

The senior officials of the new Copenhagen Police were employed by the state, whereas the force proper was municipal.

12 Strand, Efterforskningens anatomi. Kriminalpolitiet 1863-2007, (Jurist- og Økonomforbundets Forlag 2011), pp. 27-60. Christensen, Fra det evige politi til projektpolitiet (Jurist- og Økonomforbundets Forlag 2012), ch. 3. 
The Reform, which was clearly British-inspired, since - in the eyes of the Danish National Liberal politicians - England was the ideal liberal society, thus contained a number of elements. The most important, however, was that the Copenhagen Police were now divided into three separate departments: the uniformed police department, the security (or detective) police department and the department of health and public morals. In the light of the New Year's Revolt, one would have thought that the most urgent political problem would be the hard-hitting, rod-swinging practices of the police, but the truth is that "high policing" was the real obstacle. Therefore, the establishment of an independent "security police department" (or Criminal Investigation Department) was the true innovation of the 1863 Reform.

In connection with the question whether the new detectives should wear uniforms, the Parliament had a lengthy discussion of the "spying, prying and lying" of the old police, from which the politicians, on one hand, wanted to dissociate themselves. On the other hand, the Minister of Justice concluded it would be "outright ridiculous if those who monitor criminals walk around so that everybody can recognise them", and therefore, the detectives should be in plain clothes - just like their role models, i.e. the famous detectives of Scotland Yard.

The officers of the Copenhagen CID should also possess special characteristics, i.e. be "impossible to bribe, wily, and gifted with the faculty of combination". In 1863, the CID was manned with 17 officers, but doubled in size in a year. The department wanted the most skilled officers, which was also reflected in both wages and ranks. Obviously, the detective department was intended as an elite unit.

\section{Investigative Techniques}

The 1863 Reform introduced British "low policing" in Denmark, but through detective constable J.C. Søller's colourful "Police Memoirs" (1896), we are reminded that this did not mean that the old habits of "high policing" were totally renounced. Søller recounts how, in the course of duty, he associated with the suspected thief, forger and procurer, Karen Grønbæk, also known as Madam Bjørn. At the outset, Søller had a rather guilty conscience because his suspicion had not been very well-founded. Nevertheless, he disguised himself as a spendthrift shipmaster, Mr Andresen from Elsinore, and actually succeeded in gathering the necessary evidence against Ms Grønbæk. Proudly, Søller adds that his disguise was so efficient that even his superiors were deceived! ${ }^{13}$

Still, it was not this kind of undercover procedure that characterized the new detective department of the Copenhagen Police. Concurrent with the enactment in 1866 of a new Criminal Code, which stated the general rule that criminal acts should be publicly prosecuted, and a number of bills meant to change the criminal procedure from an inquisito- 
rial to an accusatorial procedure - which, in the words of the Minister of Justice, implied that the police now had to become "a true investigating police" - the Copenhagen CID adopted new, scientifically based methods of investigation. Not only did the detectives make use of the (at the time) modern contraptions of telephones and the telegraph, in 1868, they also began to publish daily "Police Intelligence Reports" with systematic information on missing persons and goods. An organised system of photographic records and rogues' galleries were likewise established, and the police took up modern investigative techniques in everyday policing. ${ }^{14}$

When, for instance, the French anthropologist, Alphonse Bertillon, developed a method for the identification of criminals, the Copenhagen Police soon adopted his so-called anthropometry as well as its distinctive scientific language. "Anthropometry" means human body measurement, and Bertillon came up with a system that contained 11 different measurements for the variations of human features. Eyes, for instance, were measured on a scale comprising 40 different colours. Ears could be described as horizontal, rectangular or oval, and the same with hands, feet, arms and legs; add to this the registration of unique characteristics such as scars and tattoos. In 1900, the adoption of the Bertillon system resulted in the establishment of a separate unit within the Copenhagen Police by the name of the Anthropometric Bureau.

In the beginning of the twentieth century, dactyloscopy (fingerprint identification) revolutionised the investigation process and in fact laid the groundwork for today's biometrics, such as DNA profiling.

\section{The Old Detectives Are Gone}

In 1871, the police outside Copenhagen were reformed, modelled on the 1863 Reform. Similar to the situation in the capital, the police commissioners were employed by the state, but the (scant) police forces were municipal. In 1911, a small state police force was established as a national CID in order to supplement the municipal forces. ${ }^{15}$ In 1919, all detectives of the local police districts became state employees, and in 1938, the state also assumed responsibility for the former municipal uniformed police forces by establishing a single national police force, Rigspolitiet. However, the traditional distinction between uniformed police and plainclothes detectives was rigidly upheld, and, as shown by the Danish police historian Frederik Strand, this segregation remained a reality until the sheer number of criminal activities in the 1980s made it necessary to let the uniformed police participate in detective work proper; at the same time, there was a realisation that combating complicated transnational crimes, such as drug trafficking, outlaw motorcycle gangs and organised crime, required new kinds of experts with analytical skills that

Strand (2011), ch. 2.

Stevnsborg (2010), ch. 5. 
older detectives did not possess. New technologies and the computerisation of police work, resulting in modern monitoring and modern "intelligence-led policing" therefore necessitated additional staff, such as data technicians, data managers and IT specialists. ${ }^{16}$

As a consequence, the classical distinction between uniformed police and detectives was abolished in the 2007 Police Reform, which, on one hand, changed the Danish police into "one single unified unit," and, on the other hand, opened up for new groups of personnel. So, today the old detectives are gone, but, as mentioned in the introduction, their function is still pivotal. "To prevent, investigate and solve crime" remains a core police task - which was not the case initially, when it was all about plush and bread. 